\title{
Study on Carbonate Reservoir Diagenesis of the Eastern Margin of the Caspian Basin----A case Study on North Truva Oilfield
}

\author{
Wang Shuqin ${ }^{1, a^{*}}$, Li Jianxin ${ }^{1, b}$, Zhao Wenqi ${ }^{1,2, c}$, Sun Meng ${ }^{1, d}$, \\ Zhang Diqiu ${ }^{2, e}$ \\ ${ }^{1}$ Research Institute of Petroleum Exploration and Development, Petrochina \\ ${ }^{2}$ China University of Geosciences (Beijing) \\ a'wshuqin@petrochina.com.cn, ${ }^{b}$ lijianxin1@petrochina.com.cn, 'zhaowenqi@petrochina.com.cn, \\ dsunmeng2014@petrochina.com.cn, e1291734515@qq.com
}

Keywords: Carbonate reservoir, diagenesis, diagenetic evolution, diagenetic facies

Abstract: The diagenesis of the Carboniferous carbonate reservoirs in the eastern margin of the Caspian Basin was studied by taking North Truva Oilfield as an example. Through analyzing the various types of diagenesis mechanisms, phases and evolution processes, combined with well logs and coring data, it was considered that evaporation dolomitization and reflux-seepage dolomitization occurred in the area of interest and regional constructive diagenesis predominantly occurred in epigenetic phase and mesogenetic phase. According to the influence of the diagenesis of different phases on reservoirs, 4 categories of diagenetic facies and 7 subcategories of diagenetic subfacies were identified.

\section{Regional Overview}

North Truva Oilfield is located in the eastern margin of the Pre-Caspian Basin, where Carboniferous KT-I and KT-II carbonate strata are developed, which are separated by MKT zone with a thickness of $300 \mathrm{~m}$ and a maximum buried depth of $6000 \mathrm{~m}$. 2 layers and 14 sublayers can be divided, including Г6-Г1, В5-В1, Б2-Б1 and А3-А2 from bottom to top, which have experienced various types of diagenetic environments, multiple phases of diagenesis and several tectonic transformations. Since carbonate rock is very sensitive to diagenesis due to its soluble property, active chemical property and brittleness, its original appearance and pore structure are greatly changed after experiencing the diagenetic transformation of various phases and types. The pore space and evolution process of carbonate reservoirs are very complex that have influenced the formation and storage of oil and gas pools.

\section{Major Diagenetic Types and Features}

According to the observation and description of core casting thin sections, scanning electron microscopy, cathodoluminescence, electron microprobe and rock fabric analysis, the Carboniferous carbonate rocks in the eastern margin of the Pre-Caspian Sea have experienced 6 types of diagenesis, among which, dissolution, dolomitization and fracturing are constructive for forming pores and improving reservoir permeability; compaction, pressolution, cementation and filling are destructive for reservoir permeability. Present reservoir space is the final product for the long-term interaction of destructive and constructive diagenesis.

Compaction. After the deposition of carbonate sediments, with the formation of overlying sediments, burial diagenetic environment is formed, when compaction takes place with the gradually increasing of overburden pressure. Compaction predominantly occurs in 
shallow-moderate burial stage, representing the phenomenon that grains are closely packed and contact by point, line and inlay, moreover, grains are deformed and fractured ( Photo 1), resulting in the number of intergranular pores and matrix micro-pores drastically reducing.

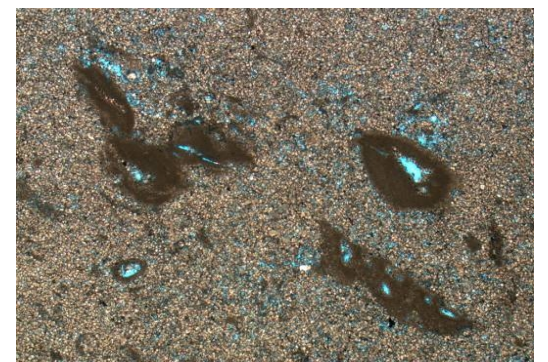

Arenite represents elongated shape due to compaction

Photo 1 Compaction

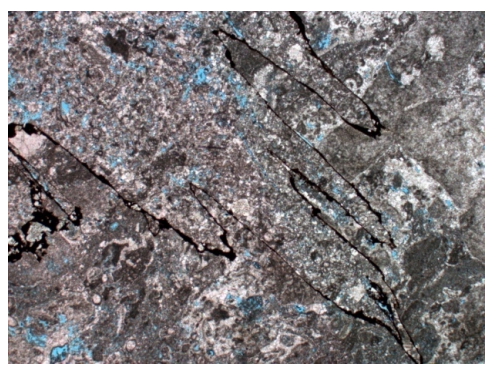

pressolved fracture

\section{Photo 2 Pressolution}

Pressolution. Pressolution predominantly occurs in moderate-deep burial stage, when dentate suture parallel and subparallel to bed plane can be seen in cores and thin sections, which are predominantly filled by organic matter, asphalt, clay, pyrite and misshapen dolomite ( Photo 2). Generally, suture is formed by pressolution. The static pressure of overlying sediments is vertical to bed plane, resulting in calcium carbonate dissolve, soluble components move out, and insoluble components remain in the vicinity of the suture. The suture can not only cut particals and the diagenetic fractures of early stage, but also can be cut by the structural fracture of late stage. The soluble matters formed by pressolution can migrate to other pores, thereby destroying the fillings of the pores, thus, the pressolution is a destructive diagenesis.

Cementation and Filling. Cementation and filling refer to the loose sediments are cemented by the minerals (cement) precipitated from pore solution, it generally takes place in grainstone, including the precipitation of the sediment from primary pores and the fillings of the chemical sediments from secondary pores. Cementation can not only makes the amount of pores decreasing, but also can resist compaction, resulting in part of primary pore preserved. Cementation of the area of interest is an important factor to affect reservoir quality.

Fillings and cements include carbonate minerals (micrite calcite $(6.13 \%)$, calcsparite $(15.38 \%)$, dolomite $(0.23 \%))$ and authigenic clay minerals $(0.2 \%)$, siliceous matter $(0.15 \%)$, fluorite $(0.05 \%)$, gypsum and celestite. Statistics from the fillings show ( Fig.1) the destruction of the filling and cementation to pore are predominantly caused by the cementation of calcsparite and the filling of micritic calcite, while the other authigenic minerals are low in content and play an limited role on pore destruction.

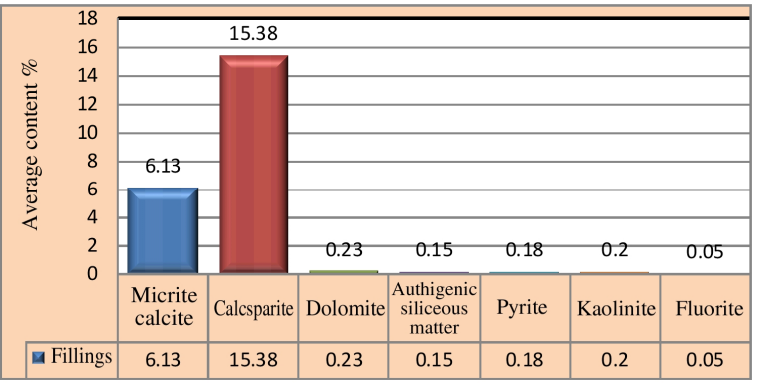

Fig.1 Statistics of the Carboniferous carbonate

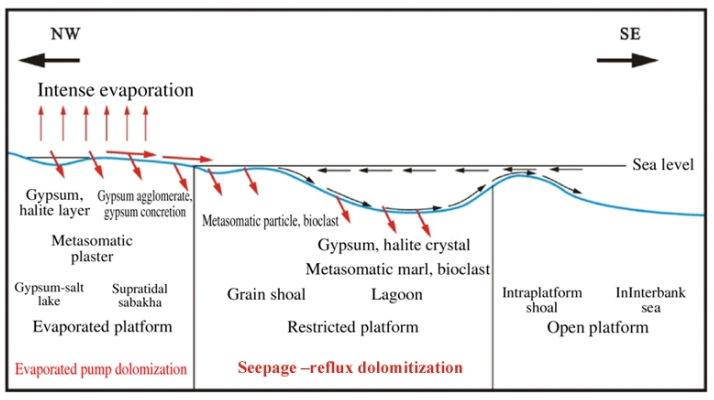

Fig.2 Carboniferous dolomitization mode

Dolomitization. The dolomitization of the Carboniferous carbonate rocks in North Truva Oilfield includes evaporation pump dolomitization, reflux-seepage dolomitization, mixed water dolomitization and burial dolomitization, with evaporation pump dolomitization, reflux-seepage 
dolomitization taking dominance, while mixed water dolomitization and burial dolomitization are not extensive and the dolomite formed by which has limited amount and generally represents dispersed fillings. The two major dolomitization patterns are shown in Fig.2 and the dolomite features are shown in Table 1.

Evaporation pump dolomitization: it occurs in supratidal Sabkha environment, where creatures are scare, a small amount of powder crystals are symbiotic with evaporation minerals, such as gypsum and halite, with high shale content. In profile, it represents evaporate rocks are interbeded with dolomite, or dolomite is interbeded with thin gypsum, gypsum-containing tuberculosis, aggregations. It is predominantly distributed in A3 and A2 sublayer to the north of A4-L6-KB1 well-tie line.

Reflux - seepage dolomitization: it occurs in supratidal Sabkha, gypsum-salt lake and lagoon since the high salinity brine replaces normal marine sediments (grain shoal or lagoon sediments) through the seepage flowing down and to the flank. It represents rhombohedral crystal shape and microcrystalline - powder crystal structure under SEM, with a small amount of slabby and cylindrical sypsum pseudomorphic crystal. Residual grain structure and bilclastic structure can be seen and completely replaced grainstone and bioclasts can't be seen. Bology is less in amount and more in categories. Dolomitization is heterogenetic with various degrees. Intense dolomitization shows foraminifer shell is dolomitized to cryptocrystalline dolomite, while slight dolomitization shows lime mud matrix is dolomitized, but bioclastes, such as brachiopods is not dolomitized, which is still composed of calcite. In plane and profile, it is symbiotic with grain shoal and lagoon and distributes in A3 and A2 sublayer to the south of A4-L6-KB1 well-tie line.

Table 1 Comparison of the features of the two major Carboniferous dolomitizations of North Truva Oilfield

\begin{tabular}{|c|c|c|}
\hline & $\begin{array}{l}\text { Evaporation pump } \\
\text { dolomitization }\end{array}$ & Seepage-reflux dolomitization \\
\hline $\begin{array}{l}\text { Depositional } \\
\text { environment }\end{array}$ & Evaporation platform Sabkha & Restricted platform dolomite flat \\
\hline Tidal zone & Supratidal & Inter-tidal-sub-tidal \\
\hline $\begin{array}{l}\text { Dolomite grain } \\
\text { size }\end{array}$ & Micrite & Micro-crystal-powder crystal \\
\hline $\begin{array}{l}\text { Metasomatic relict } \\
\text { texture }\end{array}$ & & Residual grain, bioclastic structure \\
\hline $\begin{array}{l}\text { Evaporation } \\
\text { minerals }\end{array}$ & $\begin{array}{l}\text { A large amount of evaporation } \\
\text { minerals, such as gypsum and } \\
\text { salt }\end{array}$ & A small amount of gypsum and halite \\
\hline $\begin{array}{l}\text { Biological } \\
\text { features }\end{array}$ & $\begin{array}{c}\text { No algae or a small amount of } \\
\text { algae }\end{array}$ & $\begin{array}{l}\text { Foraminifera, fusulinids, gastropods, } \\
\text { bivalves, ostracods, sponge spicules, } \\
\text { etc. }\end{array}$ \\
\hline Associated rocks & $\begin{array}{l}\text { Gypsum rock, salt rock, } \\
\text { gypsum tuberculosis, clumps }\end{array}$ & Grained shoal, lagoon \\
\hline $\begin{array}{l}\text { Dolomitization } \\
\text { metasomatism }\end{array}$ & Supratidal marl sediments & Grained clasts, bioclast, lagoon marl \\
\hline Distribution area & To the north of A4-L6-KB1 & To the south of A4-L6-KB1 \\
\hline
\end{tabular}

The dolomite in the area of interest is mainly distributed in A3 sublayer, followed by A2 sublayer. Drilling results indicate the dolomite with varying thickness is distributed in different horizons, showing the characteristics of a multi-layer distribution. In fact, the dolomite in the area of interest is a dolomite "diagenetic geological body" rather than "depositional geological body", with diachroneity and strata penetration property in vertical, reflecting the reflux-seepage dolomitization of high salinity brine has multi-stage and non-uniformity features.

In plane, the structure is high in the northwest part and low in the southeast part during the depositional period of A3 and A2 sublayer. Evaporate platform evolves to the north A4-L6-KB1, whereas restricted platform evolves to its south. The salinity brine formed in the gypsum-salt lake and Sabkha in the northwestern evaporate platform flow southeastwards, resulting in dolomitization 
occurs in the lime flat, grain shoal and lagoon sediments of restricted platform. The dolotimazation of A2 sublayer has poorer intensity than that of A3 sublayer, the residual un-dolotimizated grain shoal and lagoon sediments of A2 sublayer is more than that of A3 sublayer and the dolomite development degree of A2 sublayer is poorer than that of A3 sublayer.

Dissolution. Dissolution can produce a large amount of secondary pores, which is the most constructive diagenesis for the carbonate rocks in the area of interest. During the diagenetic process of carbonate rocks, with the variation in diagenetic environment and pore water property, dissolution can take place in several times. The dissolution of the Carboniferous carbonate rocks can be divided into three phases, syngenetic- parasyngenetic phase, epigenetic phase and burial phase, which are the important factors for the formation of present reservoir.

(1) Dissolution of syngenetic- parasyngenetic phase

It occurs in freshwater leaching diagenetic environment in response of the third-order sea level drop. During the depositional process of HST, the drop of secondary sea level results in the intraplatform shoal and grain shoal expose and occur dissolution under the influence of meteoric fresh water. Since deposits are not fully consolidated yet, fabric selective dissolution takes place, the soluble components, such as biological shell, gypsum and salt are dissolved and form shell dissolved pore, mold pore and crystal mould pore. Most dissolved pores are cemented by calcsparite during late diagenesis, only a small part of which is preserved as effective reservoir space.

(2) Dissolution of epigenetic phase

There are Carboniferous hiatus between $\mathrm{C} 1 \mathrm{v} 2$ and $\mathrm{C} 1 \mathrm{v} 3, \mathrm{C} 2 \mathrm{~b}$ and $\mathrm{C} 2 \mathrm{~m}, \mathrm{C} 2 \mathrm{~m} 1$ and $\mathrm{C} 2 \mathrm{~m} 2$ ( $\Gamma$ zone and MKT zone), C2 and C3. The eastern Pre-Caspian Basin is uplifted as a whole for several times, where weathering denudation of varying degrees take place, forming weathering crust reservoir. The largest hiatus exists between Bashkirian $(\mathrm{C} 2 \mathrm{~b})$ and Moscow $(\mathrm{C} 2 \mathrm{~m})$ Period, namely between $\Gamma 5$

sublayer and $Г 6$ sublayer of KT-II zone, Lower Bashkir ( $\mathrm{C} 2 \mathrm{~b} 1$ ) is generally preserved but Upper

Bashkir ( C2b2 ) is eroded; followed by the hiatus between Moscow C2m1 and C2m2, namely between $\Gamma$ zone and MKT zone, $\Gamma 1$ sublayer is eroded out, while $\Gamma 2$ sublayer is eroded; the hiatus between $\mathrm{C} 1 \mathrm{v} 2$ and $\mathrm{C} 1 \mathrm{v} 3$ and $\mathrm{C} 2$ and $\mathrm{C} 3$ is the smallest.

The C2b1 weathering denudation surface of North Truva Oilfield is obvious in most mud logs and wireline logs of existing wells. Dissolved pores and cavities are extensive in the reservoirs of Г6 and Д1 sublayer under erosion surface. Moreover, the weathering crust reservoirs are also extensive in Upper $\Gamma$ zone, indicating the dissolution of epigenetic phase mostly have fabric selectivity, generally forming karst breccias with dissolved cavities, dissolved pores and dissolved fractures. The depositional period of $\Gamma$ zone is the major development period of secondary dissolved pores.

(3) Dissolution of burial phase

The dissolution of moderate-deep burial phase is related with compacted water and organic matter acid water. During Carboniferous to Early Tertiary, with the gradually increasing of the buried depth of Carboniferous carbonate rocks, the compacted formation water related with buried depth and paloegeotemperature and the acid water generated by organic matter evolution are both helpful for burial dissolution. Burial dissolution predominantly occurs in the area with poor carbonate structure and permeability, such as the intervals of shallow water grain shoal and weathering curst. When underground water flows through these intervals, soluble substances will be selected, forming new dissolved pores, cavities and fractures and enlarging existing pores. The dissolved pores and cavities formed during burial pahse are important reservoir spaces. 


\section{Diagenetic FAcies Classification and Distribution}

Diagenetic Facies Classification and Characteristics. Carbonate diagenetic facies refer to the synthesis of diagenetic environments and diagenetic product, which is the material expression of diagenetic environment. Through the detailed study on the diagenesis and diagenetic phase of carbonate rocks, combined with the needs for oilfield development, 4 categories and 7 subcategories were divided based on sedimentary microfacies, rock types, major diagenesis, diagenetic evolution and pore combination. They are Iintense dissolution facies, II moderate-weak dissolution facies, III filling-cementation facies and IV compaction-pressolution facies ,among them, Iintense dissolution facies,II moderate-weak dissolution facies include 3 subcategories separately.

Diagenetic Facies Distribution. The IA andIIA diagenetic facies of North Truva Oilfield are distributed in the A2 and A3 sublayer of Upper Carboniferous, while IB and IIB diagenetic facies are distributed in $\Gamma$ zone of Lower Carboniferous.

\section{conclusion}

The diagensis of the carbonate reservoirs in the eastern margin of the Pre-Caspian Basin includes constructive and destructive diagensis. Constructive diagensis includes dissolution and dolomitization, forming good reservoirs with pore, dissolved cavity and fracture, which are favorable for oil and gas accumulation. Reservoirs of this type are I and II diagenetic facies, distributing in structural high part and the strata where epigenesist takes place; destructive diagensis includes compaction, cementation and filling, forming the tight reservoirs with no reservoir space, which act as the caprock of oil and gas poor and are mainly distributed in structural low.

\section{References}

[1] Esrafili-Dizaji B, Rahimpour-Bonab H. Effects of depositional and diagenetic characteristics on carbonate reservoir quality: A case study from the South Pars gas field in the Persian Gulf [J]. Petroleum Geoscience, 2009, 15(4): 325-344.

[2] Moore H C. Carbonate Reservoirs: Porosity Evolution and Diagenesis in a Sequence Stratigraphic Framework [M]. Amsterdam: Elsevier, 2001: 80-122.

[3] Lucia F J. Carbonate Reservoir Characterization [M], Beijing: Petroleum Industry Press, 2011: 16-22.

[4] Lucia, F. J., 1995, Rock-Fabric/Petrophysical Classification of Carbonate Pore Space for Reservoir Characterization: AAPG Bulletin, V.79 No.9. P1275-1300.

[5] López-Horguea M A, Iriarte E, Schröder S, et al. Structurally controlled hydrothermal dolomites in Albian carbonates of the Asón valley, Basque Cantabrian Basin, Northern Spain[J]. Marine and Petroleum Geology, 2010, 27(5): 1069-1092. 